\title{
Sosialisasi Keamananan Pangan dan Kosmetika pada Warga Aisyiyah Palangka Raya
}

\section{Socialization of Food Security and Cosmetics in Communities of Aisyiyah Palangka Raya}

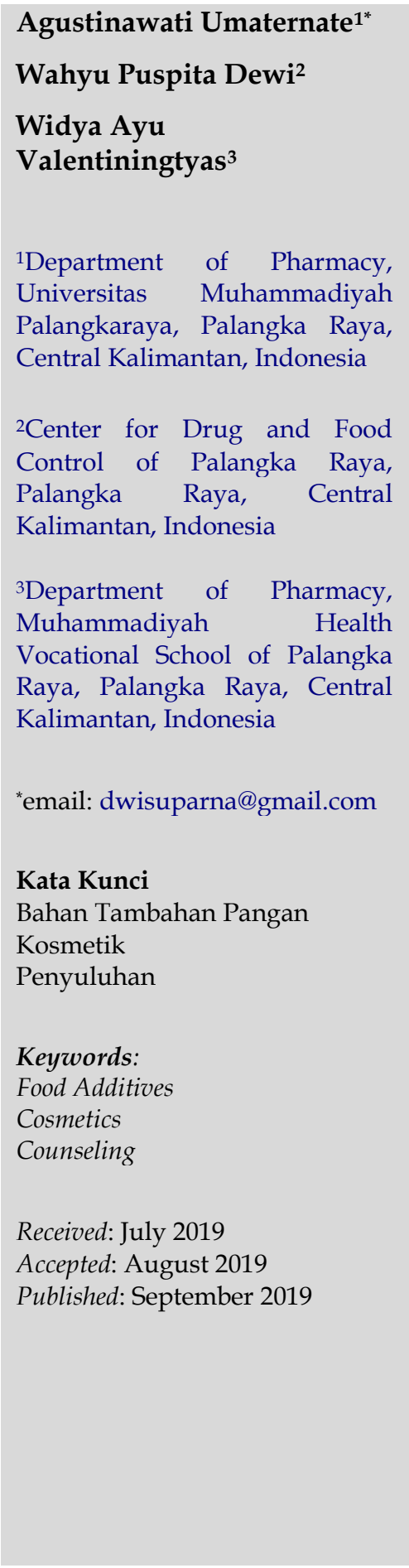

\begin{abstract}
Abstrak
Keamanan Pangan dan Kosmetika bukan hanya menjadi tanggung jawab Badan POM, Dinas Kesehatan dan jajarannya, tetapi juga perlu adanya pengawasan dari institusi pendidikan dan masyarakat. Salah satunya yang dilakukan oleh Universitas Muhammadiyah Palangkaraya melalui program Pengabdian Kepada Masyarakat. Kegiatan ini diharapkan dapat membantu kinerja pemerintah dalam pemberian informasi mengenai pangan dan kosmetika yang aman kepada masyakarakat, terutama ibu-ibu, sehingga dapat terwujud derajat kesehatan masyarakat yang setinggi-tingginya. Ibuibu Pengurus Daerah Aisyiyah Kota Palangka Raya rata-rata bekerja diluar rumah sebagai karyawati, guru, swasta, dan lain-lain. Rumah tangga sebagai basis masyarakat terkecil perlu mendapatkan pembinaan yang baik dan perhatian yang utama, karena pembangunan nasional bertumpu pada keberhasilan pembangunan manusia tersebut, dimana faktor yang mempengaruhi salah satunya adalah ketersediaan pangan yang aman dan berkualitas. Metode pelaksanaan kegiatan menggunakan metode penyuluhan/penyadaran dan pendidikan, serta simulasi pemeriksaan pada Bahan Tambahan Pangan (BTP) dan kosmetika yang tidak memenuhi persyaratan. Tujuan dari kegiatan ini adalah melindungi keluarga terhadap BTP dan kosmetika yang tidak memenuhi persyaratan kesehatan. Keluarga adalah masyarakat terkecil ini yang sangat berperan dalam penentuan pengambilan keputusan dalam asupan gizi setiap hari dan kosmetik apa yang boleh digunakan oleh keluarganya adalah ibu rumah tangga, sehingga pendidikan maupun pembinaan kepada ibu mutlak diperlukan.
\end{abstract}

\begin{abstract}
This activity is expected to help government performance in providing information on food and cosmetics that are safe to the community, especially mothers, so that the highest degree of public health can be realized. One of them was carried out by the Universitas Muhammadiyah Palangkaraya through the Community Service program. This activity is expected to help government performance in providing information on food and cosmetics that are safe to the community, especially mothers so that the highest degree of public health can be realized. The Aisyiyah Regional Administrators of Palangka Raya work on average outside the home as employees, teachers, private sector, and others. Households as the smallest community base need to get good guidance and primary attention, because national development relies on the success of human development, where the factors that influence one of them is the availability of safe and quality food. The method of implementing activities uses methods of counseling/awareness and education, as well as inspection simulations on Food Additives and cosmetics that do not meet the requirements. The purpose of this activity is to protect the family against Food Additives and cosmetics that do not meet health requirements. The family is the smallest community that plays a major role in determining the decision-making in nutritional intake every day and what cosmetics can be used by their families are housewives, so education and coaching for mothers is absolutely necessary.
\end{abstract}




\section{PENDAHULUAN}

Keamanan pangan adalah kondisi dan upaya yang diperlukan untuk mencegah pangan dari kemungkinan cemaran biologis, kimia, dan benda lain yang dapat menggangu, merugikan, dan membahayakan kesehatan manusia. Keamanan pangan telah menjadi salah satu isu sentral dalam perdagangan produk pangan (Harsojo \& Mellawati, 2009; Sanders, 1999). Penyediaan pangan yang cukup disertai dengan terjaminnya keamanan, mutu, dan gizi pangan. Tuntutan konsumen akan keamanan pangan juga turut mendorong kesadaran produsen menuju iklim persaingan sehat menuju pada jaminan keamanan bagi konsumen (Hasler et al., 2018; Di Renzo et al., 2015).

Penanganan pangan mulai mendapat perhatian serius dari pemerintah. Hal ini ditandai dengan telah diterbitkannya Peraturan Pemerintah Republik Indonesia No. 28 Tahun 2004 tentang Keamanan, Mutu, dan Gizi Pangan yang merupakan penjabaran dari Undang Undang Republik Indonesia No. 7 tahun 1996 tentang Pangan. Peraturan ini kemudian ditindaklanjuti dengan pencanangan Sistem Keamanan Pangan Terpadu (SKPT). Peraturan Pemerintah Republik Indonesia No. 28 tahun 2004 tersebut mengamanatkan bahwa Badan Pengawas Obat dan Makanan (BPOM) mempunyai kewenangan dalam pengaturan dan/atau penetapan persyaratan, standar, keamanan pangan olahan dan ritel. Salah satu sasaran pengembangan di bidang pangan adalah terjaminnya pangan yang dicirikan oleh terbebasnya masyarakat dari jenis pangan yang berbahaya bagi kesehatan (Irawan, 2016).

Keracunan pangan sering dilaporkan di media massa, meskipun menurut laporan resmi jumlah Kejadian Luar Biasa (KLB) akibat pangan di Indonesia tidaklah tinggi. Rendahnya angka KLB mungkin disebabkan oleh beberapa hal, diantaranya adalah sedikitnya pelaporan (Arisanti et al., 2018; Mabruroh \& Ciptaningtyas; 2017).
Beberapa penyakit yang disebabkan keracunan pangan seringkali dianggap sakit ringan seperti sakit perut, muntah, dan dapat sembuh tanpa perawatan maupun pengobatan sehingga tidak perlu berobat ke Puskesmas atau Rumah Sakit. Sebenarnya pelaporan keracunan pangan sangat penting untuk mengetahui status keamanan pangan suatu negara (Morse et al., 2018; Qaim \& Kouser, 2013). Yang lebih penting lagi adalah tindak lanjut pelaporan yakni investigasi keracunan pangan, yang hasil investigasinya semestinya dapat digunakan untuk penanggulangan keracunan, penyebab keracunan, penetapan penyebab keracunan, dan pencegahan keracunan serupa di masa yang akan datang (Malangu, 2015). Akhir-akhir ini tidak hanya keamanan pangan yang banyak dilaporkan, tetapi juga mengenai penggunaan kosmetika Tanpa Izin Edar (TIE) dan berbahaya juga banyak dilaporkan (Damanik et al., 2011).

Keamanan Pangan dan Kosmetika bukan hanya menjadi tanggung jawab BPOM, Dinas Kesehatan dan jajarannya, tetapi juga perlu adanya pengawasan dari institusi pendidikan dan masyarakat. Salah satunya yang dilakukan oleh Universitas Muhammadiyah Palangkaraya melalui program Pengabdian kepada Masyarakat. Kegiatan ini diharapkan dapat membantu kinerja pemerintah dalam pemberian informasi mengenai pangan dan kosmetika yang aman kepada masyakarakat, terutama ibu-ibu, sehingga dapat terwujud derajat kesehatan masyarakat yang setinggitingginya.

Sasaran dari pelaksanaan Pengabdian Masyarakat yang berjudul “Sosialisasi Keamanan Pangan dan Kosmetika Pada Masyarakat" ini adalah Ibu-ibu yang tergabung dalam Pengurus Daerah Aisyiyah (PDA) Kota Palangka Raya, Guru-guru TK/TPA Aisyiyah, dan masyarakat sekitar. Ibu-ibu Pengurus Daerah Aisyiyah (PDA) Kota Palangka Raya rata-rata bekerja diluar rumah sebagai 
karyawati, guru, swasta, dan lain-lain. Walaupun ibu-ibu tersebut memiliki pekerjaan diluar rumah, tetapi mereka tetap berperan sebagai ibu rumah tangga. Rumah tangga sebagai basis masyarakat terkecil perlu mendapatkan pembinaan yang baik dan perhatian yang utama, karena pembangunan nasional bertumpu pada keberhasilan pembangunan manusia tersebut, dimana faktor yang mempengaruhi salah satunya adalah ketersediaan pangan yang aman dan berkualitas (Istiyanto, 2016). Dalam sistem kemasyarakatan terkecil ini yang sangat berperan dalam penentuan pengambilan keputusan dalam asupan gizi setiap hari adalah ibu rumah tangga, sehingga pendidikan maupun pembinaan kepada ibu mutlak diperlukan (Kiranantika, 2013).

Banyak wanita yang menginginkan dan mendambakan tubuhnya putih mulus, wajah cantik dengan kelopak mata, dan bibirnya yang berwarna-warni, rambutnya indah terurai serta tubuhnya harum semerbak seperti bunga-bunga yang wangi. Sehingga, segala cara dilakukan untuk mendapatkan tubuh yang didambakannya tanpa memperhatikan dan memikirkan keamanan penggunaan produk kosmetika tersebut. Tujuan dari kegiatan Pengabdian ini adalah melindungi keluarga terhadap Bahan Tambahan Pangan (BTP) dan kosmetika yang tidak memenuhi persyaratan Kesehatan dalam lingkup terkecil dari komponen masyarakat yaitu dalam lingkup keluarga, melalui peran dari para ibu yang merupakan dari warga Aisyiyah Palangka Raya.

\section{METODOLOGI}

Metode kegiatan pengabdian kepada masyarakat yang dilakukan meliputi pelaksanaan kegiatan menggunakan metode penyuluhan/penyadaran dan pendidikan, simulasi cara pemilihan dan menyimpan makanan yang bergizi dan aman, simulasi pemeriksaan pada BTP yang tidak memenuhi persyaratan, uji sampel makanan yang dijual di sekitar lokasi acara yaitu Madrasah Ibtidaiyah Negeri Jl. Ramin Palangka Raya menggunakan zat kimia, serta uji sampel kosmetik yang dijual di pasar dan sering digunakan oleh masyarakat. Selain itu juga dilakukan sesi diskusi terhadap masyarakat dengan narasumber yang berasal dari pelaksana kegiatan pengabdian kepada masyarakat.

\section{HASIL DAN PEMBAHASAN}

Dari jumlah produk pangan yang diperiksa, ditemukan sekitar 9,08 sampai 10,23\% pangan yang tidak memenuhi persyaratan. Produk pangan tersebut umumnya dibuat menggunakan bahan tambahan pangan yang dilarang atau melebihi batas penggunaan, pangan yang tercemar bahan kimia atau mikroba, pangan yang sudah kadaluwarsa, pangan yang tidak memenuhi standar mutu dan komposisi serta makanan impor yang tidak sesuai persyaratan. Penggunaan bahan tambahan makanan pada jajanan berada pada tingkat yang cukup mengkhawatirkan karena dari sampel yang diperiksa $81,2 \%$ terutama untuk zat pewarna, pengawet dan pemanis. Dokumentasi sampel makanan dan kosmetik yang diperiksa disajikan pada Gambar 1 sampai 3.

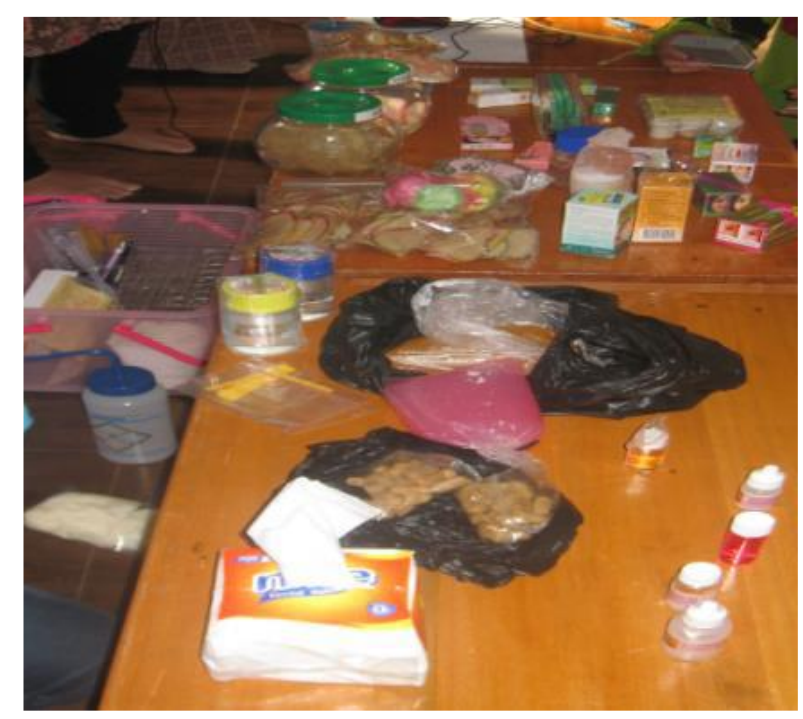

Gambar 1. Sampel jajanan 


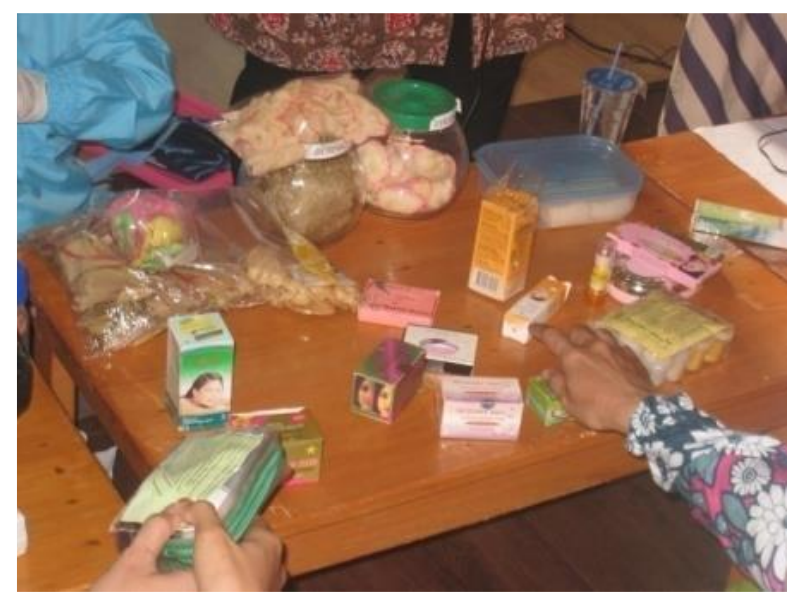

Gambar 2. Sampel kosmetik

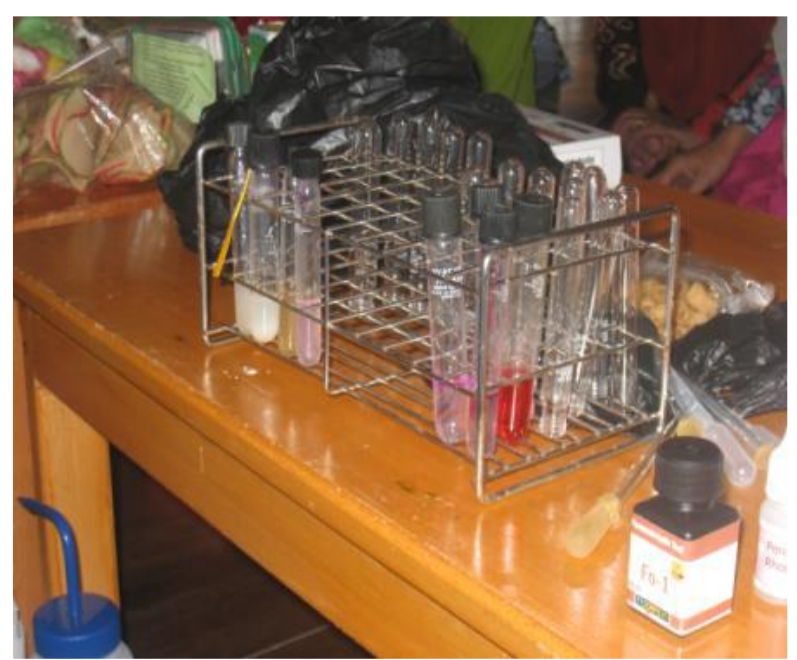

Gambar 3. Hasil uji sampel

Penggunaan bahan tambahan yang tidak sesuai adalah pewarna berbahaya (Rhodamin B, methanyl yellow, dan amaranth), pemanis buatan khusus untuk diet (siklamat dan sakarin), serta pengawet (formalin dan boraks). Badan Pengawas Obat dan Makanan telah memerintahkan untuk menarik dari peredaran produk kosmetika yang mengandung bahan berbahaya/bahan dilarang yaitu Merkuri, Hidrokuinon, Asam Retinoat, Zat warna Merah K.3 (Cl15585), Merah K.10 (Rhodamin B), dan Jingga K.1 (Cl 12075). Kandungan zat tersebut bisa memicu timbulnya reaksi alergi hingga kematian.

Kegiatan Pengabdian Kepada Masyarakat ini dapat dinyatakan berhasil karena adanya respons yang baik dan antusiasme dari ibu-ibu Pengurus Daerah Aisyiyah Kota Palangka Raya selama mengikuti kegiatan dan dapat terlaksananya kegiatan sesuai denganjadwal yang telah ditentukan. Kegiatan pengabdian ini diikuti oleh sekitar 70 orang ibu-ibu dari Pengurus Daerah Aisyiyah Kota Palangka Raya dan peserta lainnya. Keberhasilan kegiatan ini ditandai dengan banyaknya pertanyaan dari Peserta. Daftar pertanyaan peserta dalam kegiatan penyuluhan beserta jawaban dari narasumber disajikan pada Tabel I.

Tabel I. Pertanyaan peserta penyuluhan beserta jawaban dari Narasumber

\begin{tabular}{|c|c|c|}
\hline No & Pertanyaan & Jawaban \\
\hline 1 & $\begin{array}{lr}\text { Bagaimana } & \text { cara } \\
\text { mengetahui adanya } & \text { ada } \\
\text { boraks pada } & \text { bedak } \\
\text { dingin? } & \end{array}$ & $\begin{array}{l}\text { Untuk mengetahui adanya } \\
\text { boraks pada bedak dingin } \\
\text { dengan menggunakan reaksi } \\
\text { warna. Sampel bedak dingin } \\
\text { dibakar, apabila menghasilkan } \\
\text { nyala api berwarna hijau } \\
\text { menunjukkan sampel tersebut } \\
\text { mengandung boraks }\end{array}$ \\
\hline 2 & $\begin{array}{l}\text { Apakah diperbolehkan } \\
\text { kosmetika yang diberikan } \\
\text { oleh dokter karena tidak } \\
\text { tercantum nomor } \\
\text { registrasi BPOM? }\end{array}$ & $\begin{array}{l}\text { Boleh, asalkan kosmetika } \\
\text { tersebut diberikan sesuai } \\
\text { dengan indikasi yangjelas. }\end{array}$ \\
\hline 3 & $\begin{array}{l}\text { Apakah benar salah satu } \\
\text { bahaya kosmetika eye } \\
\text { shadow dapat } \\
\text { menyebabkan buta? }\end{array}$ & $\begin{array}{l}\text { Kemungkinan bisa apabila } \\
\text { terdapat bahan berbahaya pada } \\
\text { eye shadow tersebut }\end{array}$ \\
\hline 4 & $\begin{array}{l}\text { Amankah penggunaan } \\
\text { deodorant untuk menahan } \\
\text { keringat karena keringat } \\
\text { itu bukan untuk ditahan } \\
\text { tapi dikeluarkan, serta } \\
\text { efek penggunaan } \\
\text { deodorant yaitu baju } \\
\text { menjadi lengket seperti } \\
\text { lem? }\end{array}$ & $\begin{array}{l}\text { Penggunaan deodorant bukan } \\
\text { untuk menahan keringat tetapi } \\
\text { untuk menyamarkan adanya } \\
\text { bau badan. }\end{array}$ \\
\hline 5 & $\begin{array}{l}\text { Bagaimana ciri-ciri fisik } \\
\text { untuk identifikasi bahan } \\
\text { suatu makanan yang } \\
\text { mengandung } \\
\text { berbahaya? }\end{array}$ & $\begin{array}{l}\text { Ciri-ciri yang mudah dikenali } \\
\text { yaitu makanan lebih kenyal } \\
\text { atau kompak, warna lebih cerah }\end{array}$ \\
\hline 6 & $\begin{array}{l}\text { Penggunaan kosmetika } \\
\text { seperti handbody atau }\end{array}$ & $\begin{array}{l}\text { Penggunaan kosmetika seperti } \\
\text { handbody atau parfum tidak }\end{array}$ \\
\hline
\end{tabular}




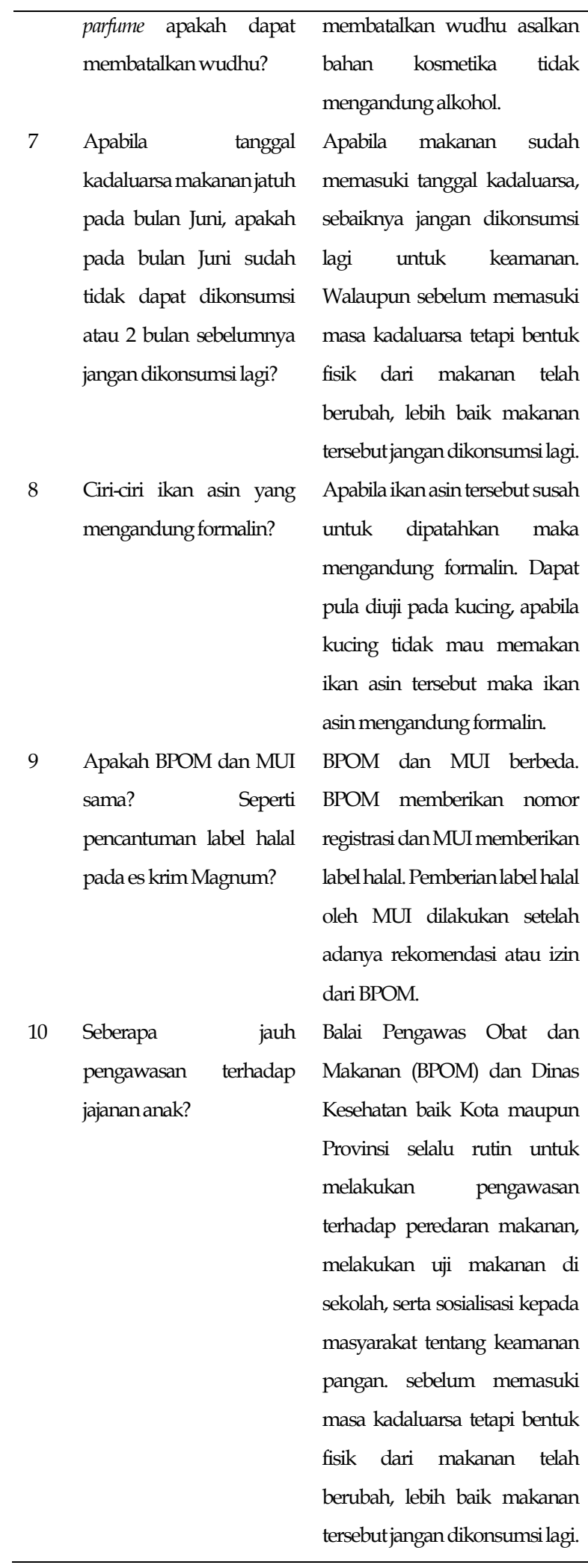

\section{KESIMPULAN}

Kegiatan Pengabdian Kepada Masyarakat mengenai "Sosialisasi Keamanan Pangan dan Kosmetika Pada Masyarakat" yang dilakukan oleh Tim Dosen Program
Studi D3 Farmasi Fakultas Ilmu Kesehatan Universitas Muhammadiyah Palangkaraya ini sangat bermanfaat. Tidak hanya untuk membantu ibu-ibu untuk mengawasi makanan anak mereka dan keamanan kosmetika yang digunakan, tetapi juga dapat membantu kinerja pemerintah dalam pemberian informasi mengenai keamanan pangan dan kosmetika. Masalah keamanan pangan tampaknya hanya masalah kecil, namun dampaknya besar terhadap kelangsungan bangsa di masa depan. Penggunaan kosmetika juga perlu diperhatikan. Ibu-ibu diharapkan lebih berhati-hati dalam penggunaan kosmetika. Jangan hanya karena ingin terlihat cantik saja, ibu-ibu tidak memperhatikan dampak yang dapat ditimbulkan oleh bahan kosmetika.

\section{UCAPAN TERIMA KASIH}

Program Pengabdian ini terlaksana atas bantuan dan dukungan pendanaan dari LPPM Universitas Muhammadiyah Palangkaraya serta dukungan narasumber dari Kepala Balai Besar Pengawas Obat dan Makanan di Palangka Raya dan partisipasi dari warga Aisyiyah Kota Palangka Raya.

\section{REFERENSI}

Arisanti, R.R., Indriani, C., Wilopo, S.A. 2018. Kontribusi agen dan faktor penyebab kejadian luar biasa keracunan pangan di Indonesia: kajian sistematis. Berita Kedokteran Masyarakat. 34(3):99-106. https://doi.org/10.22146/bkm.33852

Damanik, B.T., Etnawati, K., Padmawati, R.S. 2011. Persepsi Remaja Putri di Kota Ambon Tentang Risiko Terpapar Kosmetik Berbahaya dan Perilakunya dalam Memilih dan Menggunakan Kosmetik. Berita Kedokteran Masyarakat. 27(1):1-9. https://doi.org/10.22146/bkm.3412

Di Renzo, L., Colica, C., Carraro, A., Goga, B.C., Marsella, L.T., Botta, R., Colombo, M.L., Gratteri, S., Chang T.F.M., Droli, M., Sarlo F., De Lorenzo, A. 2015. Food safety and nutritional quality for 
the prevention of non communicable diseases: the Nutrient, hazard Analysis and Critical Control Point process (NACCP). Journal of Translational Medicine. 13:128. https:/ /dx.doi.org/10.1186/s12967-015-04842

Harsojo, Mellawati, J. 2009. Determination of Mineral Contain and Bacteria Contaminant on Organic and Nonorganic Fresh Vegetables. Indonesian Journal of Chemistry. 9(2):226-230. https://doi.org/10.22146/ijc.21534

Hasler, B., Msayla, G., Garza, M., Fornace, K., Eltholth, M., Kurwijila, L., Rushton, J., Grace, D. 2018. Integrated food safety and nutrition assessments in the dairy cattle value chain in Tanzania. Global Food Security. 18:102-113. https://doi.org/10.1016/j.gfs.2018.05.003

Irawan, D.W.P. 2016. Pangan Sehat, Aman, Bergizi, Berimbang, Beragam dan Halal. Jakarta: Forum Ilmiah Kesehatan.

Istiyanto, S.B. 2016. Pentingnya Komunikasi Keluarga: Menelaah Posisi Ibu antara Menjadi Wanita Karir Atau Penciptaan Keluarga Berkualitas. Komunika: Jurnal Dakwah dan Komunikasi. 1(2):367-388.

https://doi.org/https://doi.org/10.24090/k omunika.v1i2.801

Kiranantika, A. 2013. Pola Pengambilan Keputusan Mengenai Partisipasi Dalam Program Keluarga Berencana Pada Keluarga Muda Di Kota Malang. Sejarah dan Budaya: Jurnal Sejarah, Budaya, dan Pengajarannya. 7(1):51-61. http:/ /dx.doi.org/10.17977/sb.v7i1.4736

Mabruroh, F., Ciptaningtyas, R. 2017. Analysis of Food Poisoning in DKI Jakarta 2016 (Indonesian National Agency Drug and Food Control). In Proceedings of the 2nd Public Health International Conference (PHICo 2017). Paris: Atlantis Press. https:/ /dx.doi.org/10.2991/phico-17.2018.23

Malangu, N. 2015. Risk Factors and Outcomes of Food Poisoning in Africa. London: IntechOpen. http://doi.org/10.5772/62274

Morse, T.D., Masuku, H., Rippon, S., Kubwalo H. 2018. Achieving an Integrated Approach to Food Safety and Hygiene-Meeting the Sustainable Development Goals in Sub-Saharan Africa. Sustainability. 10(7):2394. https:/ /doi.org/10.3390/su10072394
Peraturan Pemerintah Republik Indonesia No. 28 Tahun 2004 tentang Keamanan, Mutu, dan Gizi Pangan.

Qaim, M., Kouser, S. 2013. Genetically Modified Crops and Food Security. PLOS One. 8(6):e64879. https://dx.doi.org/10.1371/journal.pone.006 4879

Sanders, T.A.B. 1999. Food production and food safety. The BMJ. 318(7199):1689-1693. https://dx.doi.org/10.1136/bmj.318.7199.168 9

Undang Undang Republik Indonesia No. 7 tahun 1996 tentang Pangan. 